Arch. Tierz., Dummerstorf 50 (2007) 1, 105-111

Royal Veterinary \& Agricultural University, Frederiksberg C, Denmark

JENS ARNBJERG

\title{
Effect of a low-growth rate on the frequency of osteochondrosis in Danish Landrace pigs (short communication)
}

\begin{abstract}
To determine the importance of feeding a low energy but high fiber containing feed ratio on the incidence of Osteochondrosis (OCD) in young Danish Landrace pigs 24 piglets were fed a low energy (788.6 joules $/ \mathrm{kg}$ ) but high fiber ration during the growth period up till 5.5 months of age. Nine piglets were fed the same feed until they had a weight of 89 - $94 \mathrm{~kg}$ (7.75 - 10.25 months of age). The pigs were slaughtered, the legs radiographed, the joints were macroscopically examined, and the findings recorded.

The radiographic and macroscopic findings typical for osteochondrosis were greatly reduced in severity and frequency when compared to earlier studies of the same genetic pool of the same age-group given a standard Danish feed ratio recommended for growing pigs (1289.6 Joules/kg).

This low growth rate regime might not be economic best for the producer of pigs used in the slaughter industry because of the unfavorable growth rate, but could be useful for the breeding stock to prevent OCD lesions in the growing fase of breeding pigs.
\end{abstract}

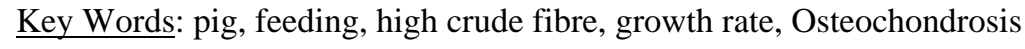

\section{Zusammenfassung}

Titel der Arbeit: Der Einfluss von begrenztem Wachstum auf die Häufigkeit von Osteochondrosefällen bei Schweinen der dänischen Landrasse (Kurzmitteilung)

Um den Einfluss auf Osteochondrosefälle zu definieren, wenn junge Schweine der dänischen Landrasse mit proteinarmem, jedoch rohfaserreichem, Futter gefüttert werden, wurden 24 Ferkel mit einem proteinarmen (788,6 Joule/kg) mit hohem Rohfasergehalt in einer Altersphase bis zu 5,5 Monaten gefüttert. Eine zweite Gruppe mit 9 Ferkeln wurde mit dem gleichen Futter bis zu einem Gewicht von 89 - $94 \mathrm{~kg}$ (7,75 - 10,25 Monate alt) gefüttert. Die Schweine wurden geschlachtet, die Beine geröntgt, die Gelenke makroskopisch untersucht und die Ergebnisse registriert.

Die für Osteochondrose (OCD) typischen Röntgen- und makroskopischen Ergebnisse zeigten im Vergleich zu früheren Studien des gleichen genetischen Stammes der gleichen Altersgruppe weitaus weniger schwere und eine reduzierte Anzahl von Osteochondrosefällen, nachdem sie mit einem für heranwachsende Schweine empfohlenem Standardfutter (1289,6 Joule/kg) gefüttert worden waren.

Dieser niedrige Zuwachsgrad kann für die Produzenten, die Schweine für die Schlachtindustrie produzieren, nicht die beste finanzielle Lösung darstellen, könnte aber für die Aufzucht nützlich sein, um OCD-Erkrankungen bei Zuchtschweinen im Laufe der Wachstumsphase zu verhindern.

Schlüsselwörter: Schwein, Fütterung, hoher Rohfaseranteil, Wachstumsrate, Osteochondrose

\section{Introduction}

Osteochondrosis (OCD) in pigs is a major predisposing factor leading to lameness, leg weakness and poor performance in slaughter pigs and breeding pigs as well (WOODARD et al., 1987; HILL, 1990a, b; JOERGENSEN et al., 1995). Osteochondrosis is defined as a nonfatal pathologic skeletal disease of unknown origin observed in several species, with a high morbidity especially in pigs raised under industrial farming conditions, where the pigs feeding regime is very intensive (JOERGENSEN et al., 1995). In the Danish 
Landrace the morbidity can be as high as $90 \%$ as was found in a radiological and pathological study of slaughtered boars, slaughtered at an approximate weight of $95 \mathrm{~kg}$ at the age of 5.5 months. An earlier radiological-follow-up study in Danish breeding sows showed that about $80 \%$ of the young sows were affected (BITTEGEKO and ARNBJ ERG, 1994a, b).

Osteochondrosis is observed in specific sites of the skeleton. In the pig, the medial condyles of the femur and humerus are the most common sites for affection of the articular-epiphyseal cartilage (JOERGENSEN et al., 1995; BETTEGEKO and ARNBJ ERG, 1994a, b). The physeal growth plate in the distal ulna is the area most often affected physeal site in the pig. OCD is generally accepted as the major reason for slow and cautious mowing due to pain and arthrosis in the joints (BITTEGEKO and ARNBJ ERG, 1994a, b). The severity and morbidity seem to decrease with the age of the breeding sow (BITTEGEKO and ARNBJ ERG, 1994b).

There has been some contradiction in the literature about the importance of the feeding regime for development of OCD. NAKANO (1984) and JOERGENSEN et al. (1995) were not able to demonstrate any difference in growth rate and the severity of the OCD, whereas BITTEGEKO et al. (1997) found a significant importance in the feeding intensity, but the homogeneity of the feeding regime could be questioned in the latter material. WOODARD et al. (1987) showed a reduced longitudinal growth of the long bones, but no changes in the development of OCD when feeding a very low protein ration. The purpose of this study was to estimate the importance of a very low growth rate by feeding a low protein and low calorie but high fibre containing diet in order to reducing the incidence of OCD in pig. By taking radiographs just after slaughtering the specific OCD sites can be evaluated and compared in frequency and severity with earlier studies of fast growing Danish Landrace piglets, slaughtered at $95 \mathrm{~kg}$ body weight at the age of about 5.5 months (JOERGENSEN et al., 1995).

\section{Material and methods}

Twenty-four piglets in three pens, Group 1, (13 gilt's and 11 barrows (castrated at the age of 3 weeks)) weaned at the age of 30 days were fed ad libitum with a high fibre, low calorie and low digestible protein whole -crop feed. The mothers (3 sisters inseminated with semen from the same boar) had been fed the same low energy feed during pregnancy and lactation period.

The feed was composed of whole crop of barley (44\%), rye (25\%) and pea (25\%) mixed with sugar-beet molasses (4\%) and mineral-mix (5338 Nor) 2\%. This feed-mixture contains $23.3 \%$ fibre, $11 \%$ crude protein and $8.7 \%$ ash in $92.1 \%$ dry matter and 63.6 feed-units/100 kg (788.6 Joules $/ \mathrm{kg}$ ). This feed-mixture is produced for dry sows to prevent gaining too much weight in the dry period.

There was some, but limited amount of straw in the pen during the entire growth period. The pigs were raised under SPF conditions at the university pig-experimental station "Sjaelland III" near Roskilde (2000) in a concrete floored pen-house with some straw as bedding ( $9 \mathrm{~m}^{2}$ pr 10 piglets). All the pigs were able to move freely in the pen and none of them exhibited signs of lameness or swelling in any of the joints at any time.

The Group 1 pigs were slaughtered at the age of 5.5 months. The weight at slaughter varied from 43 to $66 \mathrm{~kg}$ with a mean weight of $54.5 \mathrm{~kg}$.

Group 2: One of the sows produced another litter with the same father. This group was slaughtered at different ages varying from 7.75 to 10.25 months of age with their weight 
varying between 89 and $94 \mathrm{~kg}$. The feeding regime was the same, the product delivered from the same company and the feed composed and adjusted to the same content-values as group 1, but about 5 months later.

The radiographs were in both groups taken in medio-lateral projection of the left carpal and elbow area in the thoracic limb and tarsus and stifle area in the pelvic limb.

The radiographs were produced using Fuji HR-L films and "3M Trimax 16" intensifying screens. The focal cassette distance was $100 \mathrm{~cm}$. Portable X-ray Unit was used (SHOWA X-ray Co Ltd., Tokyo, 100 kV, 35 mA).

After radiographing the legs, the joints were opened and the macroscopic lesions were recorded as in the study of JORGENSEN et al (1995).

The lesions found on the radiographs were scored on a scale from 1 (normal) to 5 (very severe lesions) according to Table 1 (BITTEGEKO and ARNBJERG, 1994a). A similar scale for the subchondral bone evaluation described by BITTEGEKO and ARNBJERG (1994b) was used for the subchondral bone scoring.

As the animals in this study was from the same genetic pool as the animals used in the study of JORGENSEN et al. (1995) that study can act as the control group fed on a diet 104 feed-units/100 kg (1289.6 Joules/kg) giving a very high growth rate. That study used similar floor and housing facilities and management as in the present study.

Table 1

The scoring system for metaphyseal osteochondrosis radiological lesions (Punkte für Radiologische Metaphyseale Osteochondrose)

\begin{tabular}{l|l}
\hline Score & Description of the lesion \\
\hline I & $\begin{array}{l}\text { Slender physis, smooth physeal-metaphyseal and physeal-epiphyseal margins, no metaphyseal } \\
\text { radiolucent foci/areas, no metaphyseal flaring, lipping and slipping af epiphysis: (Normal) } \\
\text { Widened physis and metaphysis, metaphyseal lipping, small foci of irregular ossification: } \\
\text { (Mild) } \\
\text { Widened physis and metaphysis, marked area(s) of irregular ossification and/or radiolucency: } \\
\text { (Moderate) } \\
\text { Widened and deformed physis and metaphysis, very irregular ossification and/or large areas of } \\
\text { radiolucency in the metaphysis: (Severe) } \\
\text { Very wide and deformed physis and metaphysis, very irregular ossification and/or very large } \\
\text { radiolucent and sclerotic areas in metaphysis: (Very severe) }\end{array}$ \\
\hline
\end{tabular}

Results

The low energy intake resulted in a lower growth rate in the new borne piglets and the weaning pigs had a lower weaning weight compared with normal Danish landrace piglets as in the study of JOERGENSEN et al. (1995). None of the pigs showed any discomfort or lameness at movement, but they were meagre.

The respective anatomical loci (macroscopic as well as radiological) showed different scores in the different groups are seen in Tables 2 and 3. The radiological scores was a result of a two times blind reading by the same radiologist: (Score: 1: normal; 5: very severe). The macroscopically changes in the joints were of the same kind but lesser extend and severity as seen in the material of JOERGENSEN et al. (1995) and BITTEGEKO and ARNBJ ERG (1994a). Therefore only the radiographic changes are recorded.

On the radiographs as well as in macroscopic examination of group 1 the most severe changes but relative small in size were found among the largest pigs while the very small pigs did not have any lesions at all. The numeric findings of group 1 are seen in Table 2 
where a few (2) had a score of III in the Distal Ulna in $8 \%$ and 1 had the score of III in the Femoral Condyles (4 \%) and none had a higher score at all.

Table 2

Position and score of OCD lesions in Group $1(\mathrm{n}=24)$ (Position und Punkte der Osteochondroseläsionen der Gruppe 1 $(\mathrm{n}=24))$

\begin{tabular}{llllllll}
\hline Anatomical site $\backslash$ Score & I & II & III & IV & V & \multicolumn{2}{c}{ B\&A* } \\
\hline Humeral Condyles & 20 & $4(17 \%)$ & 0 & 0 & 0 & $45 \%$ & $15 \%$ \\
Proximal Radius & 24 & 0 & 0 & 0 & 0 & $0 \%$ & $0 \%$ \\
Apophysis Ulna & 24 & 0 & 0 & 0 & 0 & $0 \%$ & $0 \%$ \\
Anconeal Process & 24 & 0 & 0 & 0 & 0 & $17 \%$ & $5 \%$ \\
Distal Radius & 24 & 0 & 0 & 0 & 0 & $14 \%$ & $0 \%$ \\
Distal Ulna & 18 & $4(17 \%)$ & $2(8 \%)$ & 0 & 0 & $45 \%$ & $31 \%$ \\
Femoral Condyles & 18 & $5(24 \%)$ & $1(4 \%)$ & 0 & 0 & $55 \%$ & $7 \%$ \\
Proximal Tibia & 24 & 0 & 0 & 0 & 0 & $0 \%$ & $0 \%$ \\
Proximal Fibula & 24 & 0 & 0 & 0 & 0 & $27 \%$ & $0 \%$ \\
Distal Tibia & 24 & 0 & 0 & 0 & 0 & $52 \%$ & $5 \%$ \\
Distal Fibula & 24 & 0 & 0 & 0 & 0 & $29 \%$ & $0 \%$ \\
Talus & 21 & $3(12.5 \%)$ & 0 & 0 & 0 & $36 \%$ & $5 \%$ \\
Tarsal Bones & 24 & 0 & 0 & 0 & 0 & $0 \%$ & $0 \%$ \\
\hline
\end{tabular}

*B\&A are the procentage of pig in scores II+III and IV+V in BITTEGEKO et al. (1994b)

*B\&A sind die gesamte prozentuellen Befunden im Punkte II+III und IV+V im Material vom BITTEGEKO et al. (1994b)

In group 2 there were no clear difference in the macroscopic findings in the joints between the pigs slaughtered at the age of 7.75 and those slaughtered at 10.25 months. The numeric findings are seen in Table 3 where only 1 had a score of 3 in the Distal Ulna and none had higher score at all.

On the radiographs only small OCD-changes were observed and very little difference in the number of OCD lesions between group1 and 2. There were no differences as well in the closure of the physeal plates in the piglets with differences in age.

There were no differences between the males and females in any of the groups.

Table 3

Position and score of OCD lesions in Group 2 (n=9) (Position und Punkte der Osteochondroseläsionen der Gruppe 2 $(\mathrm{n}=9))$

\begin{tabular}{llllll}
\hline Anatomical site $S$ Score & I & II & III & IV & V \\
\hline Humeral Condyles & 7 & $2(22 \%)$ & 0 & 0 & 0 \\
Proximal Radius & 8 & $1(11 \%)$ & 0 & 0 & 0 \\
Apophysis Ulna & 9 & 0 & 0 & 0 & 0 \\
Anconeal Process & 9 & 0 & 0 & 0 & 0 \\
Distal Radius & 9 & 0 & 0 & 0 & 0 \\
Distal Ulna & 6 & $2(22 \%)$ & $1(11 \%)$ & 0 & 0 \\
Femoral Condyles & 7 & $2(22 \%)$ & 0 & 0 & 0 \\
Proximal Tibia & 9 & 0 & 0 & 0 & 0 \\
Proximal Fibula & 9 & 0 & 0 & 0 & 0 \\
Distal Tibia & 9 & 0 & 0 & 0 & 0 \\
Distal Fibula & 9 & 0 & 0 & 0 & 0 \\
Talus & 7 & $2(22 \%)$ & 0 & 0 & 0 \\
Tarsal Bones & 9 & 0 & 0 & 0 & 0 \\
\hline
\end{tabular}




\section{Discussion}

The respective anatomical loci and radiological changes were the same as described more thoroughly by JOERGENSEN et al. (1995) and BITTEGEKO and ARNBJ ERG (1994a) were also observed in this material. The severity and numbers of affected pigs was decreased in this material and showed reduced radiological scores in the different groups are shown in Tables 2 and 3. There were no pigs scoring more than III, where as there were a high number in these classes in the material of BITTEGEKO and ARNBJ ERG (1994a) and up till $80 \%$ of the Bittegeko material had some form of OCD, where as only $31 \%$ of the present material had some form of OCD.

The genetic pool, age and housing of the pigs in study group 1 and 2 were comparable to the slaughter pigs in the study of JOERGENSEN et al. (1995) and therefore that material serves as a control group. The weight of the pigs, however, was $95 \mathrm{~kg}$ in the study of JOERGENSEN et al. (1995) carried out in research stations own by the Danish Slaughterhouses but the pigs were fed a commercial feed made for fast growing piglets in commercial Danish pig farms. Therefore the major difference between the earlier studies and Group1 was the very low growth rate, which was the result of the feeding regime that was extremely low in energy (788.6 Joules/kg versus 1289.6 Joules/kg). In Group 2 the low growth rate resulted in a much later age 7.75 - 10.25 months at slaughter reaching the weight of about $90 \mathrm{~kg}$, but still showing a significant lower OCD rate and severity compared to the findings of JOERGENSEN et al. (1995).

In previous published studies the difference in energy intake between the groups was no more than a few per cent, and even the lowest growth rates were, therefore, not nearly as slow as those in the present studies. NAKANO et al. (1984) were not able to demonstrate a correlation between growth rate and OCD. CARLSON (1988) showed reduction of OCD when feeding $70 \%$ the amount of the same feed after 6 weeks after weaning, than that of the control group pigs were fed.

In this study the examination of the joints was performed at the same age in group 1 and in group 2 at an older age - but the same weight at slaughter as the study of JOERGENSEN et al. (1995) where OCD lesions were found in $90 \%$ of the pigs.

As it was shown by BITTEGEKO and ARNBJERG (1994b), that the radiological OCD lesions decrease over a longer period of time. Therefore the results primarily should be compared within a similar age of the pigs as it is done in group1. However, if the bodyweight-load could have some influence group 2 was performed to compare that fact. In both groups in this study the dramatic reduction of as well the number of joint and the severity of the OCD lesions were found (8 \% had score III against $35 \%$ having score III or more in the earlier study (BITTEGEKO and ARNBJ ERG, 1994b).

The present study shows reduction in as well severity as frequency as it was suggested in the study of BITTEGEKO et al. (1997) under African condition and to some extent by CARLSON et al.(1988). CARLSON et al. (1988), however, did not have the same reduction in growth rate as in this study. The reason is probably first of all because the difference in the feeding regime started at an older age of the piglets in the earlier studies. In this study there was a very different kind of feed and not only a $30 \%$ reduction in energy intake in part of the growing period. The feed in this study was special already when the sow was pregnant and continued during the weaning period as well, which too is different from the design of CARLSON et al. (1988).

Even the present study comprises a limited number of pigs; the differences in the scores are so clear and very dramatic. 
When compared to the study of BITTEGEKO et al. (1997) a study with 58 sows fed on a high energy feed, a very different picture was found. The epiphysis of ulna had a score of III or more in $47 \%$ compared to $8 \%$ had score III and no higher score in group 1 and 11\% in group 2 in the present study. The housing and the genetic pool were comparable in all these studies. The lesser body weight in group 1 is taken into consideration in group 2 and even then the OCD scoring is similar at an older age so the weight of the body cannot by the course of the difference.

It appears that the total energy intake is very influential. That was the reason for selecting the specific dry-sow-diet used in this study.

High fibre is reported to result in lesser palatability and there was observed a problem with the palatability of the feed in this study. Some of the piglets did not show much interest in it in the beginning and, therefore, did not eat much during the first weeks after weaning. This could help explaining the great difference in weights between the piglets despite the fact that they all had free access to the feed throughout the entire study period.

It has previously been shown that feeding a ration with a protein content of $12 \%$ compared to a protein content of $16 \%$ but with a normal high-energy content resulted in a shorter size of the long bones, but no difference in the severity of OCD (WOODARD et al., 1987).

It has previously been stated that OCD is caused by a hereditary disposition and that trauma often can be the factor that triggers clinical signs of the abnormality (NAKANO and AHERNE, 1988).

The type of diet used in these experiments may not be optimal for piglets produced primarily for meat production, due to slow growth rates. It could however, be some useful elements in the alternative for the future breeding stock because of a lower risk of large osteochondrotic changes in the joints (HILL, 1990b), and, thusly, better locomotor function. Further large-scale studies must be carried out to show how the different levels of growth rate influence OCD and to investigate whether there is a lower limit of growth rate, for which OCD is not a major problem. However, other studies have show that high fibre content can been used to get more satiated and thereby less excitable pigs (WENK and ZURCHER, 1990).

From the present study it can be stated that in the pig does the nutritional factor have a very great influence upon the development of OCD if the growth rate is reduced dramatically during the entire growth period.

\section{References}

BITTEGEKO, S.B.P.; ARNBJERG, J.:

Radiological aspects on the course of development of porcine epiphyseal osteochondrosis (OCD) from 42 up to 147 Days of Age. J. Vet. Med. A 41 (1994a), 369-376

BITTEGEKO, S.B.P.; ARNBJERG, J.:

The sequelae of distal ulna physeal dyschondroplasia (osteochondrosis) lesions in breeding swine - a radiological investigation in Danish Landrace pigs. J. Vet. Med. A 41 (1994b), 377-384

BITTEGEKO, S.B.P.; ARNBJERG, J.; KESSY, B.M.:

A comparative radiological study of osteochondrosis/dyschondroplasia in slow growing and fast growing landrace pigs raised under low or high plane of nutrition using commercial feeds. Tanzanian Vet. J. 17 (1997), 123-132

CARLSON, C.S.; HILLEY, H.; MEUTEN, D.J.; HAGAN, J.M.; MOSER, R.L.:

Effect of reduced growth rate on the prevalence and severity of osteochondrosis in gilts. Am. J. Vet. Res. 49 HILL, M.: (1988), 396-402

Causes of degenerative joint disease (osteoarthrosis) and dyschondroplasia (osteochondrosis) in pigs. J. Am. 
Vet. Med. A 147 (1990 a), 07-113

HILL. M.:

Economic relevance, diagnosis and counter measures for degenerative joint disease (osteoarthrosis and dyschondroplasia (osteochondrosis) in pigs. J. Am. Vet. Med. A. 147 (1990b), 254-259

JOERGENSEN. B.; ARNBJERG. J.; AASLYNG, M.:

Pathological and radiological investigations on osteochondrosis in pigs, associated with leg weakness. J. Vet. Med. A. 42 (1995), 489-504

NAKANO, T.; AHERNE, F.X.; BRENNAN, J.J.; THOMPSON, J.R.:

Effect of growth rate on the incidence of osteochondrosis in growing swine. Can. J. Anim. Sci. 64 (1984), 139-146

NAKANO, T.; AHERNE, F.X.:

Involvement of trauma in the pathogenesis of osteochondritis dissecans in swine. Can. J. Vet. Res. 52 (1988), 154-155

WENK, C.; ZURCHER, U.:

Energy utilization by swine of nutritive fiber rich by-products from the milling and food industry. Arch. Tierernähr. 40 (1990), 423-430

WOODARD, J.C.; BECKER, H.N.; POULOS, P.W. Jr.:

Effect of diet on longitudinal bone growth and osteochondrosis in swine. Vet. Pathol. 24 (1987), 109-117

Received: 2005-05-26

Accepted: 2005-12-14

Authors address

JENS ARNBJERG, Associate professor, DVM, DipECVDI

Royal Vet. \& Agricultural University

Dyrlaegevej 32

1870 FREDERIKSBERG C, DENMARK

E-Mail: jar@kvl.dk 